\title{
Strategy And Planning As An Enabler For Strategy Execution In South African Municipalities
}

\author{
J. H. Leibbrandt, North-West University, South Africa \\ C. J. Botha, North-West University, South Africa
}

\begin{abstract}
Literature confirmed that whilst progress has been made in recent years, there is still a pressing need amongst communities in South Africa for improved service delivery. There is also increasing frustration and anger at the inability of municipalities to do what is expected of them. Municipalities, in general, have a poor record in respect of execution of strategy.
\end{abstract}

The research problem - "what prevents municipalities in South Africa to successfully execute its strategies and what can be done to address the situation?"- will be answered and dealt with when the findings and conclusions relevant to each enabler are discussed.

Research and literature to date focused primarily on planning and strategy formulation but neglected the very important execution process. Whilst strategy execution is a dismal failure in most organizations, to date, very little research has focused on it.

Managers and their employees must apply new ways of thinking. Today's high performing organizations are able to bridge the strategy-execution gap due to the fact that their strategies translate to specific operational goals, their employees understand the context and purpose of their work, and they can readily measure how well they are performing.

Keywords: Structure; Strategy; Planning; Execution; Municipalities

\section{INTRODUCTION}

hile some frameworks of organizational effectiveness go in and out of fashion, one that has
persisted and is still used today is the McKinsey 7 ' $\mathrm{S}$ ' framework. The framework was developed in
1980 by Tom Peters and Robert Waterman, two consultants working at the McKinsey \& Company consulting firm. The basic premise of the model is that there are seven (7) internal aspects of an organization that need to be aligned if it is to be successful. Waterman et al. (1980: 18) demonstrated the interconnectedness of these seven (7) elements (Kaplan \& Norton, 2006: 4).

The McKinsey framework allows for questions to be asked concerning where the organization is in terms of each element. Adjustments and realignment can then be effected before the implementation process starts. They argued that this improved the chances of success. To date, the 7 ' $\mathrm{S}$ ' framework is still extensively used by managers and consultants and is considered as one of the cornerstones of strategy execution and organizational analysis (Srivastava, 2005: 57; Pugk \& Hickson, 2007: 168-172).

\section{LITERATURE REVIEW}

Waterman et al. (1980: 14) constitutes that all managers and consultants know that the process of organizing is much more than charts, boxes, dotted lines and position descriptions, but all too often this is forgotten and when change is required, the structure gets changed. 
Strategies are formulated to achieve the organizational purposes which include strategic intent, vision, focus, mission, goals, and strategic objectives (Waterman et al., 1980: 20). In Figure 1, it becomes clear that the 7 'S' framework displays the interconnections of the organizational elements.

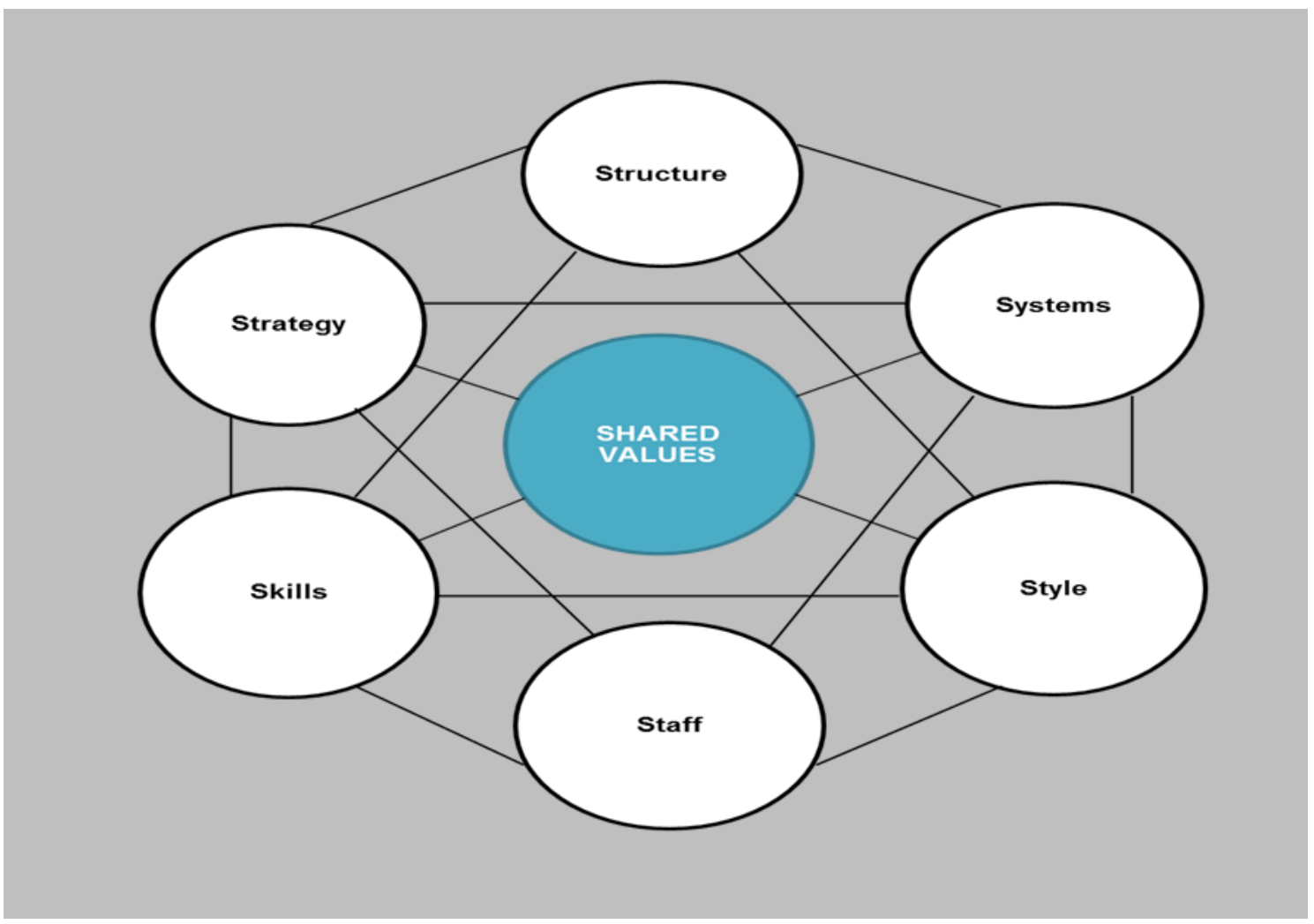

Waterman et al. (1980: 18)

Figure 1: Mckinsey 7 'S' Framework

- $\quad$ Structure: The organization's structure comprises of five components - (1) jobs and the authority to perform the job, (2) the grouping of jobs into divisions or departments, (3) the span of control, (4) the mechanisms of coordination, and (5) the operating model, policies and procedures (Waterman et al., 1980: 19).

- $\quad$ Shared values: The values shared by the members of the organization that differentiate the organization from others. The shared values are the core of the 7 ' $S$ ' framework because it defines the core themes around which an organization rallies and drives the corporate culture (Waterman et al., 1980: 24).

- $\quad$ Staffing. The number and types of employees and individual and group competencies required by the organization to execute its strategy successfully (Waterman et al., 1980: 23).

- $\quad$ Systems: The systems and processes required by an organization to execute its strategy on a daily basis for example, information systems, capital budgeting systems, reward systems, performance management system, etc. (Waterman et al.,1980: 21)

- Skills: The required organizational skills, capabilities and distinctive competence required to ensure successful strategy execution (Waterman et al., 1980: 24)

- Style: How top management allocates their time and attention, symbolic actions, their leadership skills, and the way the management team is perceived by the rest of the organization (Waterman et al.,1980: 21)

The virtue of the McKinsey 7 ' $S$ ' framework is that it draws attention to some important organizational interconnections and why these interconnections are relevant in trying to effect change. The 7 ' $\mathrm{S}$ ' framework is a simple way to illustrate that the job of executing strategy is one of creating fits and harmonizing the seven (7) S's (Waterman et al. (1980: 1). 


\section{PROBLEM INVESTIGATED}

This research focused on the municipalities in the Gauteng Province in South Africa and the problems with strategy execution. Strategy and planning, as a specific enabler, are the focus and are considered to address the problem. The inability to execute strategies is one of the main problems in local government (SA, 2009a: 4) and is unfortunately still not receiving the urgent attention it requires. Execution is a discipline on its own which represents a process of interrelated activities that enables an organization to successfully execute strategy. An organization will, in the absence of a well-formulated execution plan, not achieve the expected strategic outcomes (Hrebiniak, 2005: $3)$.

\section{RESEARCH OBJECTIVES}

The research objectives were 1) to review the literature and determine the role of strategy and planning in the strategy execution frameworks of Mckinsey's seven 7 ' $S$ ' framework for strategy execution and 2) to analyze the findings of the empirical study and to make recommendations towards the improvement of strategy execution within Gauteng municipalities in South Africa if one put strategy and planning under scrutiny.

\section{RESEARCH METHODOLGY}

After careful consideration of the various research approaches, it was decided to utilize quantitative research, which is exploratory in nature, as the primary data collection method for the purpose of this survey.

\section{Structured Questionnaire}

A quantitative research approach was utilized and a structured questionnaire with closed questions was chosen as the preferred tool and method to arrive at the expected results.

The purpose of the questionnaire was to establish the municipality's current state and ability to execute strategies. "Strategy Execution", in this questionnaire, refers to the execution or implementation of strategies, plans and policies of the municipality. The questionnaire was handed out at the survey sessions. The participants were willing to be honest as their anonymity was assured (Salkind, 2007: 138). The questionnaire posed the questions (statements) on a four-point Likert Scale with a fifth "Don't Know" option. The participants had to consider the following options and respond to each statement:

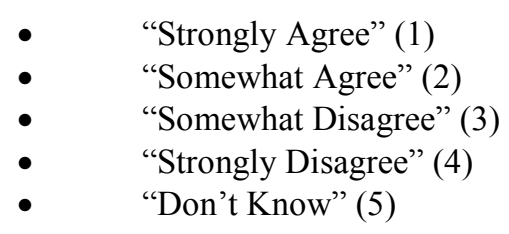

A factor analysis was used to identify the structure and factors of the enabler strategy and planning and through this process, the structural validity of the survey was also determined (Pietersen and Maree, 2007: 219). According to Pietersen and Maree (2007: 219), the purpose of a factor analysis is to determine which statements (items) belong together due to the fact that it measures the same factor.

\section{Target Population}

The population of this study comprised of all the senior and middle managers in the Metropolitan, District and Local Municipalities and within the Gauteng Province.

The targeted population consisted of those senior and middle managers responsible for strategy formulation and planning, execution and service delivery, as well as two union leaders (shop stewards) representing the two largest unions per municipality. The target population comprised of 351 targeted participants. 


\section{Sampling}

To ensure sample adequacy, it was decided to use the entire target population as the study sample. All Metropolitan, District and Local Municipalities, as well as the targeted role players within the Gauteng Province, will thus form part of the survey.

The target population consisted of 412 people, a total of 379 completed questionnaires were collected, and the 379 who responded formed the study population.

\section{RESULTS}

\section{Frequencies And Descriptive Statistics}

Table 1.

The frequency and descriptive statistical results of the "Strategy and Planning" enabler are reported in

Table 1: Frequencies and Descriptive Statistics

\begin{tabular}{|c|c|c|c|c|c|c|c|c|c|}
\hline \multirow[b]{2}{*}{$\begin{array}{c}\text { Statement } \\
\text { Q2.1 }\end{array}$} & \multirow[b]{2}{*}{ Strategy And Planning Statements } & 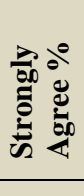 & 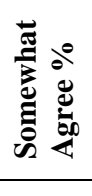 & 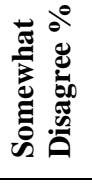 & 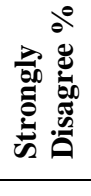 & 泀苛 & \multirow[t]{2}{*}{ 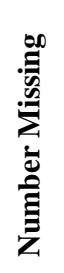 } & \multirow{2}{*}{$\sum_{\Sigma}^{\tilde{E}}$} & \multirow{2}{*}{ 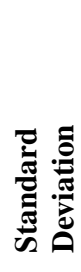 } \\
\hline & & 1 & 2 & 3 & 4 & 5 & & & \\
\hline 1 & $\begin{array}{l}\text { A Growth and Development Strategy } \\
\text { (GDS) has been approved by the } \\
\text { Council. }\end{array}$ & 52.5 & 20.3 & 3.2 & 8.2 & 15.8 & 0 & 1.61 & 0.95 \\
\hline 2 & $\begin{array}{l}\text { The Growth and Development Strategy } \\
\text { (GDS) is fully aligned to the political } \\
\text { mandate (Outcome 9, Manifesto, etc). }\end{array}$ & 31.4 & 30.9 & 9.5 & 9.5 & 18.7 & 0 & 1.96 & 0.99 \\
\hline 3 & $\begin{array}{l}\text { The political mandate (Outcome } 9 \\
\text { Manifesto, etc) is translated into policy } \\
\text { directives. }\end{array}$ & 30.9 & 34.6 & 11.3 & 5.3 & 17.9 & 0 & 1.89 & 0.87 \\
\hline 4 & $\begin{array}{l}\text { A } 5 \text { Year Integrated Development Plan } \\
\text { (IDP) has been approved by the } \\
\text { Council. }\end{array}$ & 83.1 & 9.0 & 1.3 & 2.9 & 3.7 & 0 & 1.21 & 0.61 \\
\hline 5 & $\begin{array}{l}\text { The } 5 \text { Year IDP and the Growth and } \\
\text { Development Strategy (GDS) are fully } \\
\text { aligned. }\end{array}$ & 37.7 & 31.4 & 12.4 & 7.7 & 10.8 & 0 & 1.89 & 0.95 \\
\hline 6 & $\begin{array}{l}\text { The } 5 \text { Year IDP and the annual SDBIP } \\
\text { are fully aligned. }\end{array}$ & 51.5 & 28.2 & 9.0 & 5.0 & 6.3 & 0 & 1.65 & 0.86 \\
\hline 7 & $\begin{array}{l}\text { Lekgotlas are annually scheduled } \\
\text { before the start of the planning } \\
\text { processes (IDP, budget and SDBIP). }\end{array}$ & 59.1 & 20.3 & 9.2 & 5.0 & 6.3 & 0 & 1.57 & 0.87 \\
\hline 8 & $\begin{array}{l}\text { The municipality utilizes external } \\
\text { advisory boards (NGO's, universities, } \\
\text { experts, etc) to advise on certain } \\
\text { specialized matters. }\end{array}$ & 33.2 & 33.8 & 14.0 & 10.3 & 8.7 & 0 & 2.01 & 0.99 \\
\hline 9 & $\begin{array}{l}\text { Management at all levels participated } \\
\text { in the formulation of the Growth and } \\
\text { Development Strategy (GDS). }\end{array}$ & 27.2 & 24.5 & 17.9 & 19.0 & 11.3 & 0 & 2.32 & 1.12 \\
\hline 10 & $\begin{array}{l}\text { Management at all levels participated } \\
\text { in the formulation of the } 5 \text { Year IDP. }\end{array}$ & 54.1 & 25.9 & 7.7 & 8.2 & 4.2 & 0 & 1.69 & 0.94 \\
\hline
\end{tabular}


(Table 1 continued)

\begin{tabular}{|c|c|c|c|c|c|c|c|c|c|}
\hline \multirow[b]{2}{*}{$\begin{array}{l}\text { Statement } \\
\text { Q2.1 }\end{array}$} & \multirow[b]{2}{*}{ Strategy And Planning Statements } & 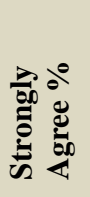 & 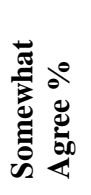 & 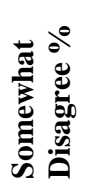 & 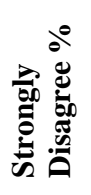 & 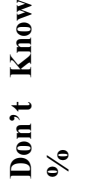 & \multirow{2}{*}{ 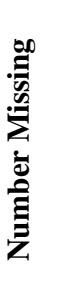 } & \multirow{2}{*}{$\stackrel{\Xi}{\stackrel{\Xi}{\Xi}}$} & \multirow{2}{*}{ 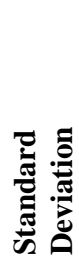 } \\
\hline & & 1 & 2 & 3 & 4 & 5 & & & \\
\hline 11 & $\begin{array}{l}\text { Risks are planned for in the Growth } \\
\text { and Development Strategy (GDS). }\end{array}$ & 23.5 & 30.1 & 17.9 & 13.7 & 14.8 & 0 & 2.26 & 1.03 \\
\hline 12 & The municipality has a Risk Register. & 55.7 & 24.5 & 5.3 & 5.3 & 9.2 & 0 & 1.56 & 0.84 \\
\hline 13 & $\begin{array}{l}\text { The Risk Register is at least on a } \\
\text { quarterly basis reviewed. }\end{array}$ & 31.4 & 29.0 & 17.7 & 10.0 & 11.9 & 0 & 2.07 & 1.00 \\
\hline 14 & $\begin{array}{l}\text { Scenario forecasting forms part of the } \\
\text { municipality's planning process. }\end{array}$ & 16.4 & 34.3 & 19.5 & 17.2 & 12.7 & 0 & 2.43 & 1.01 \\
\hline 15 & $\begin{array}{l}\text { The outcomes of the Growth and } \\
\text { Development Strategy (GDS) are } \\
\text { spatially mapped. }\end{array}$ & 19.3 & 33.8 & 15.3 & 11.9 & 19.8 & 0 & 2.25 & 0.98 \\
\hline 16 & $\begin{array}{l}\text { At departmental level the SDBIP is } \\
\text { fully cascaded into operational } \\
\text { implementation plans. }\end{array}$ & 48.3 & 28.2 & 12.4 & 7.1 & 4.0 & 0 & 1.77 & 0.94 \\
\hline 17 & $\begin{array}{l}\text { Every project has a leader who is } \\
100 \% \text { responsible to see that the } \\
\text { project is executed. }\end{array}$ & 30.1 & 36.4 & 17.7 & 10.8 & 5.0 & 0 & 2.10 & 0.98 \\
\hline 18 & $\begin{array}{l}\text { Every project is cascaded into a } \\
\text { detailed project charter. }\end{array}$ & 23.2 & 35.6 & 23.2 & 12.4 & 5.5 & 0 & 2.26 & 0.97 \\
\hline 19 & $\begin{array}{l}\text { The Growth and Development } \\
\text { Strategy (GDS) is formally reviewed at } \\
\text { least every } 2 \text { years. }\end{array}$ & 14.5 & 24.8 & 20.1 & 18.7 & 21.9 & 0 & 2.55 & 1.05 \\
\hline 20 & $\begin{array}{l}\text { Strategy implementation is formally } \\
\text { reviewed at least twice a month. }\end{array}$ & 9.8 & 17.7 & 29.8 & 28.8 & 14.0 & 0 & 2.90 & 0.99 \\
\hline
\end{tabular}

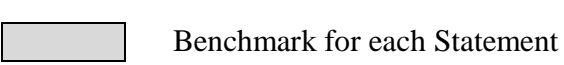

The benchmark (ideal) in terms of responses for every statement is marked (filled with grey) in Table 1 . In this section of the questionnaire, the response benchmark for all the statements is one (1) "Strongly Agree".

The "Strategy and Planning" enabler serves the purpose of determining the status of strategies and plans of the municipalities. The main purpose and overall focus of the survey is to identify the main reasons and contributing factors preventing the municipalities to effectively and efficiently execute their strategies. Strategy formulation and planning in local government is well and almost over regulated and controlled.

The results in Table 1 confirm that "Strategy and Planning" is relatively under control and that the municipalities are complying with the requirement of having a strategy and/or plan.

The mean of almost all the statements in this section of the questionnaire is below 2.5. This outcome supports the literature where it states that organizations generally spend a lot of time and energy on the formulation of strategies. It also supports and complies with the local government's legal framework. The detail results of the enabler will be discussed as part of the factor analysis.

\section{Factor Analysis}

A factor analysis was conducted on the 20 statements as to explore the factorial structure of the enabler. The results of the KMO Measure of Sampling Adequacy, P-value of Bartlett's Test of sphericity, and the Determinant of Correlation Matrix are reported in Table 2. 
Table 2: KMO, Bartlett's Test And Determinant Of Correlation Matrix

\begin{tabular}{|l|c|}
\hline \multicolumn{1}{|c|}{ KMO, Bartlett's Test And Determinant Of Correlation Matrix: Strategy And Planning } & Value \\
\hline Kaiser-Meyer-Olkin Measure of Sampling Adequacy (KMO) & 0.914 \\
\hline P-Value of Bartlett's Test of Sphericity & $<0.001$ \\
\hline Determinant of Correlation Matrix & $2.058 \mathrm{E}-005$ \\
\hline
\end{tabular}

The KMO Measure of Sampling Adequacy measured 0.914 (superb, according to Field, 2009: 647) which suggests that the sample size is adequate for factor analysis. The P-value of Bartlett's Test of sphericity returned a value smaller than 0.05 , indicating that correlations between statements were sufficiently large for factor analysis. The Determinant of Correlation Matrix measured > 0.00001, which indicates that there is not too severe multicollinearity in the data.

After exploring various multifactor solutions, it was decided to use four (4) factors to explain the "Strategy and Planning" section. The four (4) factors each had eigenvalues above Kaiser's criterion of 1.0 (Field, 2009: 671) and, in combination, cumulatively explained a favourable $62.75 \%$ of the variance. The four-factor solution also made theoretical sense. The results of the factor analysis for the "Strategy and Planning" section are reported in Table 3.

Table 3: Pattern Matrix ${ }^{a}$

\begin{tabular}{|c|c|c|c|c|c|}
\hline \multicolumn{1}{|c|}{ Enabler: Strategy And Planning } & \multicolumn{1}{l|}{} \\
\hline $\begin{array}{c}\text { Statement } \\
\text { Q2.1 }\end{array}$ & Factor 1 & Factor 2 & Factor 3 & Factor 4 & Project \\
\cline { 2 - 6 } & Planning & $\begin{array}{c}\text { Growth And } \\
\text { Development } \\
\text { Strategy (GDS) }\end{array}$ & $\begin{array}{c}\text { Planning, Risk } \\
\text { And Compliance }\end{array}$ & $\begin{array}{c}\text { Five (5) Year Integrated } \\
\text { Development Plan (IDP) }\end{array}$ & Communalities \\
\hline 18 & .871 & .038 & -.109 & .084 & .678 \\
\hline 17 & .815 & .058 & -.056 & .161 & .657 \\
\hline 20 & .516 & -.156 & .134 & .254 & .449 \\
\hline 16 & .494 & .049 & .262 & .109 & .568 \\
\hline 2 & -.074 & .875 & .102 & .006 & .820 \\
\hline 1 & -.106 & .699 & -.147 & .282 & .383 \\
\hline 5 & .149 & .599 & .055 & .056 & .650 \\
\hline 15 & .258 & .528 & .138 & .221 & .579 \\
\hline 3 & .080 & .494 & .186 & & .515 \\
\hline
\end{tabular}

\begin{tabular}{|c|c|c|c|c|c|}
\hline \multicolumn{6}{|c|}{ Enabler: Strategy And Planning } \\
\hline \multirow[b]{2}{*}{$\begin{array}{l}\text { Statement } \\
\text { Q2.1 }\end{array}$} & Factor 1 & Factor 2 & Factor 3 & Factor 4 & \multirow[b]{2}{*}{ Communalities } \\
\hline & $\begin{array}{l}\text { Project } \\
\text { Planning }\end{array}$ & $\begin{array}{c}\text { Growth And } \\
\text { Development } \\
\text { Strategy (GDS) }\end{array}$ & $\begin{array}{c}\text { Planning, Risk } \\
\text { And Compliance }\end{array}$ & $\begin{array}{l}\text { Five (5) Year Integrated } \\
\text { Development Plan (IDP) }\end{array}$ & \\
\hline 19 & .418 & .431 & .065 & -.135 & .563 \\
\hline 11 & .289 & .402 & .309 & -.045 & .633 \\
\hline 9 & .313 & .355 & .252 & -.187 & .521 \\
\hline 13 & -.032 & .055 & .832 & -.053 & .615 \\
\hline 12 & -.147 & .018 & .789 & .173 & .597 \\
\hline 10 & .327 & .003 & .374 & .238 & .508 \\
\hline 7 & .227 & -.064 & .369 & .089 & .348 \\
\hline 14 & .308 & -.279 & .344 & -.131 & .533 \\
\hline 8 & .180 & -.226 & .296 & -.113 & .303 \\
\hline 4 & .065 & -.091 & .042 & .463 & .273 \\
\hline 6 & .214 & -.245 & .153 & .462 & .561 \\
\hline $\begin{array}{l}\text { Cronbach's } \\
\text { Alpha }\end{array}$ & 0.817 & 0.903 & 0.792 & 0.562 & \\
\hline Factor Mean & 2.24 & 2.12 & 1.89 & 1.43 & \\
\hline $\begin{array}{l}\text { Factor } \\
\text { Standard } \\
\text { Deviation } \\
\end{array}$ & 0.78 & 0.77 & 0.68 & 0.64 & \\
\hline
\end{tabular}


All the statements on each factor loaded above 0.3, except for statement 8 which had a loading of 0.296 on factor 3 , which is close to 0.3 and therefore still deemed acceptable. The enabler mean calculated at 2.00 , which is an indication that the respondents tended to agree with the statements contained in this section of the questionnaire.

\section{DISCUSSION}

\section{Factor One (1): Project Planning}

Statements 16, 17, 18 and 20 loaded on factor one and are related to the "Project Planning" factor. Statements 18 and 17 have factor loadings above 0.8 , whilst statements 16 and 20 also loaded satisfactorily with factor loadings of 0.49 and 0.51 , respectively. The communalities for all the statements are all above 0.3 .

The factor mean calculated at 2.24, which is an indication that the respondents tended to agree with the statements contained in the factor. According to the item-level results presented in Table 1, it seems that the respondents tended to agree that the Service Delivery and Budget Implementation Plan (SDBIP) is cascaded into operational implementation plans (mean of 1.77), that every project has a project leader who is responsible for execution (mean of 2.10), and that every project is cascaded into a detailed project charter (mean of 2.26).

The regular (at least twice a month) monitor and review of strategy execution is, however, an area of concern that requires attention (mean of 2.90).

The "Project Planning" factor shows good reliability with a Cronbach's Alpha Coefficient of 0.817.

\section{Factor Two (2): Growth And Development Strategy (GDS)}

Statements 1, 2, 3, 5, 9, 11, 15 and 19 loaded on factor two and these statements are related to the "Growth and Development Strategy" factor. Statement 2 has a factor loading of above 0.8, whilst statements 1, 3, 5, 11, 15, and 19 also loaded satisfactorily with a factor loading of above 0.4. Statement 9 also loaded satisfactorily above 0.3 . The communalities for all statements are above 0.3 .

The factor mean calculated at 2.12 which is an indication that the respondents tended to agree with the statements contained in the factor.

According to the item-level results presented in Table 1, it seems that the respondents tended to agree that a Growth and Development Strategy (GDS) has been approved by the municipality (mean of 1.61), that the GDS is fully aligned to the political mandate (mean of 1.96), that the political mandate is translated into policy directives (mean of 1.89), that the five-year Integrated Development Plan (IDP) and the GDS are fully aligned (mean of 1.89), that management at all levels participated in the formulation of the GDS (mean of 2.32), that risks are planned for in the GDS (mean of 2.26), and that the outcomes of the GDS are spatially mapped (mean of 2.25).

The respondents, however, tended to disagree with the statement that the strategy (GDS) is regular reviewed (mean of 2.55) which could be an area that requires attention.

The "Growth and Development Strategy" factor shows good reliability with a Cronbach's Alpha Coefficient of 0.903 .

\section{Factor Three (3): Planning, Risk And Compliance}

Statements $7,8,10,12,13,14$ loaded on factor three and are related to the "Planning, Risk and Compliance" factor. Statements 12 and 13 have factor loadings of above 0.7, whilst statements 7, 10 and 14 also loaded satisfactorily with a factor loading of above 0.3. Statement 8 ("The municipality utilizes external advisory boards") loaded at 0.296 , which could be rounded to 0.3 . The communalities for all the statements are all above 0.3. 
The factor mean calculated at 1.89 , which is an indication that the respondents tended to agree with the statements contained in the factor and that it is viewed as relatively positive and under control. The mean of each statement in this factor is below 2.5, which indicates that the respondents tended to agree and that no serious problem areas exist.

According to the item-level results presented in Table 1, it seems that risk registers are compiled and implemented (mean of 1.56) and that it is reviewed on a regular (at least quarterly) basis (mean of 2.07), that external advisory boards are utilized by the municipalities to advise on specialized matters (mean of 2.01), that meetings are annually proactively scheduled before the start of the planning processes (mean of 1.57), and that scenario forecasting forms part of the planning process (mean of 2.43).

The "Planning, Risk and Compliance" factor shows good reliability with a Cronbach's Alpha Coefficient of 0.792 .

\section{Factor Four (4): Five (5)-Year Integrated Development Plan (IDP)}

Statements 4 and 6 loaded on factor four and are related to the "Five-Year Integrated Development Plan $(I D P)$ " factor. Both statements have factor loadings of above 0.4 on this factor. The communalities for statement 6 are above 0.3 , whilst statement 4 is 0.273 .

The factor mean calculated at 1.43 and it seems that the respondents tended to agree with the statements contained in the factor. According to the item-level results presented in Table 1, it seems that the respondents tended to agree that the municipality has a Five-Year Integrated Development Plan (IDP) which has been approved by the council (mean of 1.21) and that the SDBIP and IDP are well-aligned (mean of 1.65).

The "Five-Year Integrated Development Plan (IDP)" shows a Cronbach's Alpha Coefficient of 0.562, which could be regarded as a relatively low reliability index (Field, 2009: 675). This could be caused by the low number of statements (2) in the factor (Cortina, 1993).

\section{Factor Correlation Matrix ${ }^{a}$}

The Pearson correlations between the extracted factors for the "Strategy and Planning" enabler are reported in Table 4.

Table 4: Factor Correlation Matrix ${ }^{\mathrm{a}}$

\begin{tabular}{|l|l|c|c|c|c|}
\hline \multicolumn{1}{|c|}{ Factors: Strategy And Planning } & $\mathbf{1}$ & $\mathbf{2}$ & $\mathbf{3}$ & $\mathbf{4}$ \\
\hline $\mathbf{1 .}$ & Project Planning & $\mathbf{1 . 0 0 0}$ & 0.475 & 0.529 & 0.217 \\
\hline $\mathbf{2 .}$ & Growth and Development Strategy & 0.475 & $\mathbf{1 . 0 0 0}$ & 0.412 & 0.116 \\
\hline 3. & Planning, Risk and Compliance & 0.529 & 0.412 & $\mathbf{1 . 0 0 0}$ & 0.243 \\
\hline 4. & Five (5) Year Integrated Development Plan (IDP) & 0.217 & 0.116 & 0.243 & $\mathbf{1 . 0 0 0}$ \\
\hline
\end{tabular}

The correlations between all factors within the "Strategy and Planning" enabler were medium to large, except for correlations between the factor "Five-Year Integrated Development Plan (IDP)" and other factors.

\section{CONCLUSIONS}

The "Strategy and Planning" enabler in municipalities is well regulated and determines the roadmap for South African municipalities towards achieving the desired objectives and ultimately services and customer care. It is evident from the empirical results that the enabler calculated results close to the ideal.

Strategy and planning sets the scene and is the starting point in the execution process and the ultimate outcome and success of the execution process will be measured in terms of services and customer care. 


\section{RECOMMENDATIONS}

The strategy formulation process must interpret the political mandate and clearly, in a simplified manner, set the long- and medium-term direction of the municipality in terms of Key Performance Areas (KPAs). The strategy must facilitate cross-functional integration and collaboration across all functions and departments of the municipality. If possible, external experts and stakeholders should form part of the formulation process.

The role-players responsible for the execution process must form part of the strategy formulation team. The strategy should be drafted with the execution thereof in mind and should be cascaded into a credible Five-year Integrated Development Plan (IDP) with clear Key Performance Indicators (KPIs) and targets. The execution plan (SDBIP) must convert the IDP into annual programs, projects and activities which deal with the detail of who, what, when and where.

\section{AUTHOR INFORMATION}

Johan Leibbrandt was awarded his $\mathrm{PhD}$ degree in Business Administration from the North-West University in 2013. He acted as the CEO of the Kempton Park/Tembisa Metropolitan Local Council and served in this position from 1994 to 2002. He was then appointed as the Deputy City Manager of the Ekurhuleni Metropolitan Municipality and served in this position from 2002 to 2010 . He is currently employed as a Director at PricewaterhouseCoopers (PwC) and currently works in Kenia (Africa) where he is the local government specialist advisor. Email: leibbrandt.johan@ke.pwc.com.

Christoff Botha was awarded his Ph.D. degree in Industrial Sociology from the Potchefstroom University for Christian Higher Education. He is a Chartered Human Resource Practitioner and registered with the South African Board of Personnel Practitioners. He also specialises in gender studies and woman in mining. Apart from research and writing, he also has been practicing Employment Relations on a part-time basis for more than 20 years. He is currently in the position of Associate Professor at the North-West University, Potchefstroom Business School in South Africa. Email: Christoff.botha@nwu.ac.za.

\section{REFERENCES}

1. Field, A. (2009). Discovering statistics using SPSS. 3rd edition. London: Sage Publication.

2. Flood, P. C., Dromgoole, T., Carroll, S. J., \& Gorman, L. (eds). (2000). Managing strategy implementation. Oxford: Blackwell Publishers.

3. Hrebiniak, L. G. (2005). Making strategy work: Leading effective execution and change. Upper saddle River, NJ: Wharton School Publishing.

4. Kaplan, R. S. \& Norton, D. P. (2006). Why system, not structure, is the way toward strategic alignment: A historic perspective. Balanced Scorecard Report, 8 (4): 1-16, Jul/Aug.

5. Pietersen, J. \& Maree, J. G. (2007). Standardisation of a questionnaire. In Maree, J.G., ed. First steps in research. Pretoria: Van Schaik.

6. Salkind, J. (2007). Exploring research. 6th ed. Uppersaddle River, N.J.: Pearson.

7. Srivastava, S. C. (2005). Managing core competence of the organization. Vikalpa, 30(4), 49-63, Dec.

8. Waterman Jr., R. H., Peters, T. J., \& Phillips, J. R. (1980). "Structure is not organization". Business Horizons. Vol. 23, pp. 14-26. 


\section{NOTES}

